\section{Халатов Сергей}

Александрович,

доцент кафедры гражданского процесса Уральского государственного юридического университета, кандидат юридических наук kafedra.gp/agmail.com
DOI: $10.18572 / 1812-383 X-2020-11-38-40$

\section{Значение реформы судебного надзора в гражданском процессе в 2018 году}

В статье исследуется вопрос о последствиях изменения отдельных норм Гражданского процессуального кодекса РФ, регулирующих надзорное производство. На основании результатов изучения практики Президиума Верховного Суда Российской Федерации делается вывод о минимальном воздействии изменений на судебную практику по гражданским делам.

Ключевые слова: надзорное производство, судебный надзор, президиум, судебные акты.

The Meaning of the Reform of Judicial Supervision in the Civil Procedure in 2018

Khalatov Sergey A.

Associate Professor of the Department of Civil Procedure of the Ural State Law University

PhD (Law)

The article examines the issue of the consequences of changes in certain norms of the Code of Civil Procedure, regulating supervisory proceedings. Based on the results of studying the practice of the Presidium of the Supreme Court of the Russian Federation, it is concluded that the changes have a minimal impact on judicial practice in civil cases.

Keywords: supervisory proceedings, judicial review, Presidium, court decisions. 